\title{
Development and Implication of Applied Tourism Higher Education in Germany
}

\author{
LIU Haiyang ${ }^{1,2}$ \\ ${ }^{1}$ Institute of History and Culture, Changchun Normal \\ University \\ ${ }^{2}$ The Northeast Institute of Geography and Agroecology, \\ Chinese Academy of Sciences \\ Changchun, China \\ haiyang0796@163.com
}

\author{
XU Liping \\ Institute of History and Culture, Changchun Normal \\ University; \\ Changchun, China \\ 543569644@qq.com
}

\begin{abstract}
Germany started to develop higher education of tourism after World War II, which came into being with the development of German tourism. Taking one of the world's famous educational countries Germany as the core and based on the background of German higher education, this paper discusses the curriculum setting, curriculum classification, teaching methods, and training objectives for the development of tourism higher education in Germany. From the perspective of application, it comprehensively and systematically analyzes the implication of Germany higher education of tourism classification to China.
\end{abstract}

Keywords-German higher education; Application type; Tourism teaching; Curriculum

\section{INTRODUCTION}

Tourism higher education is important to train tourism talents, and it is also an important support for the long-term survival and development of tourism. Higher education of tourism in Germany develops after the Second World War. With the development of the German tourism, tourism education in Germany develops spontaneously, and then continues to rise. The relevant research and development of tourism higher education have also come into being. German's tourism education is mainly in vocational and technical college with the original "dual system" mode, and combines tourism occupation education and academic education to train talents required by tourism of different levels and industries. With the expanding of tourism market, tourism talents and market demand also have changed. In the subsequent development of tourism education, tourism higher education, including comprehensive university, university of applied science and cooperative running schools, will gradually develop into today's high level academic research such as masters and Ph.D. The development of higher education in Germany has promoted the further research and development of German tourism education.

\section{DEVELOPMENT OF APPLIED TOURISM HIGHER EDUCATION IN GERMANY}

In German University of Applied Science, the development of tourism management professional like a raging fire, the hardware and software facilities, tourism management professional based on practice, therefore, independent single professional tourism management under the multi University of Applied Sciences, such as Germany, Munich should use tourism management professional, Bolaien Science University Hull University of Applied science tourism business professional management, Stuart Zehnder University of Applied Sciences, leisure and tourism management professional, it emphasizes the students during the future employment and occupation development oriented, learning, and require students to have a travel related practice experience in the tourism industry enterprises accounted for the entire time to work in school $25 \%$.

The tourism education of cooperative education colleges in Germany is based on the dual education system. The classification of tourism courses varies with different enterprises and institutions. It mainly takes the tourism occupation needs of travel agents, hotels, local and regional tourism association, tourism intermediaries in the tourism industry as a guide, and conducts school-enterprise cooperation and joint training. Tourism enterprise and colleges provide fund jointly to train excellent tourism talents who adapt to the needs of the post. Students need to master both theoretical knowledge and practical knowledge, covering the training of theory, practice and application. When entering the college, students need to sign relevant training contract with tourism enterprises. The professional courses require students to have one year of professional workout in the different departments of the training enterprises. Students who are trained under the mode can better complete the tasks assigned by the enterprise, and have strong practical operation ability and job adaptability. They are available to the job at any time.

\section{CURRICUlum SETting FOR Higher EdUCATION OF APPLIED TOURISM IN GERMANY}

The major setting of tourism higher education in Germany changes with the different types of colleges. The 
comprehensive university (such as the University of Munich) has 6-7 semesters during the undergraduate, and students have to earn 180-240 credits at the phase of undergraduate. Its professional courses related to tourism include geography, economics, sociology and law.

In the university of applied sciences in Germany (taking the Munich University of Applied Sciences as an example), its tourism higher education courses also include tourism training, health care, tourism forums, foreign learning experience and other courses. It can open courses flexibly according to students' interests and the emerging tourism industry demands in the market. Tourism higher education in Germany allows students to enter other countries to have diversified university studies, increase practical skills and international experience, and learn transnational strategies. Germany pays more attention to the general education on the requirements of tourism managers.

In the cooperative running colleges in Germany (such as Berlin Cooperative Education Institution), its tourism-related majors are tourism economy and commercial economy. Its basic teaching is mainly based on courses such as business, economics, law, accounting, statistics, foreign language and business economics. The professional learning includes hotel and tourism management, tourism geography, tourism marketing, hotel services, human resources management and catering course management.

\section{THE TRAINING GOAL OF APPLIED TOURISM HIGHER EDUCATION IN GERMANY}

The University of Applied Sciences in Germany trains practical talents with certain theoretical basis for tourism industry. Their students are trained talents who have certain professional basic knowledge of tourism, and can work independently in the tourism industry. Compared to the comprehensive colleges in Germany, the training in university of applied science in Germany pays attention to the applicability over the systematization of theoretical knowledge. For example, the training goal of the tourism management major in the Munich University of Applied Science is: tourism practitioners who take tourism as occupational orientation and are able to work independently. Students are required to acquire the basic knowledge of tourism such as hotels, travel agency, transportation, and can independently complete relevant work in tourism industry. Train practical talents and compound talents for the tourism industry in Germany.

The cooperation of tourism education colleges in Germany and enterprises is conducted through communication, discussion, negotiation and contract signing. The college teaches students theoretical knowledge according to the needs of tourism enterprises and teaching tasks, and let students acquire the basic core courses of tourism industry, such as hotel management, travel agency management, tourism geography. Enterprises provide fund to train students in social practice positions with a series of tourism training courses. In the training process, hotels, travel agencies and travel network enterprises send enterprises' core backbone to teach students the training courses. The tourism enterprise teaching application management center outside the school is mainly formed by relevant professional teachers and instructors sent by the school. According to the teaching plan, understand the task and purpose of each teaching link and determine the instructor and tourism enterprise related personnel. Implement the specific teaching requirements, conditions and methods through the communication and coordination with the tourism enterprises. Timely evaluation and feedback is also an important part of school-enterprise cooperation. The evaluation of school-enterprise cooperation is mainly carried out in two aspects: the school is responsible for assessing the training of students' learning ability, the improvement of teachers' quality and the effective use of teaching resources. The tourism enterprises are responsible to assess the students' post practice in training course outside the school, tourism operations and service capabilities. This model can better promote both parties in the cooperation to work smoothly in tourism education, so as to better serve the tourism enterprises, improve the overall service level of tourism industry, and ultimately achieve a winwin objective.

\section{THE IMPACT OF GERMAN'S APPLIED TOURISM HIGHER EDUCATION ON CHINA}

\section{A. Clearly identify school running level}

First of all, China's tourism management major has not yet formed a system like the tourism education in German's comprehensive university, applied science university and cooperative running colleges. In terms of the classification of tourism education, the level division is not clear, major division is not obvious, and target positioning is not specific. Therefore, China's tourism management students, no matter undergraduates or junior college graduates, have similar choice after graduation, mainly engaged in hotels and travel agency. While German's tourism-related majors, from the analysis of comprehensive university, applied science college and cooperative running college, the positioning and training objectives of colleges are very clear and have very clear divisions, Colleges of different levels have different training objectives.

Second, from the perspective of curriculum and teaching mode, whether it is tourism-related comprehensive university, applied science university or cooperative school in Germany, its curriculum and teaching models are unique. But China's tourism education still generally takes tourism geography, hotel management, tour guide services, tourism psychology into their courses. China's tourism colleges have not been classified into academic research school and practical application school. The unclear division and target positioning let the tourism education neglect the influence of the characteristics and development law of tourism needs, and fail to train talents with special characteristics according to colleges' own development needs, not able to better serve the tourism industry.

Third, China should increase the adjustment of tourism education reform. With the joint collaboration of the Ministry of Education and tourism schools, the opening of major conferences and the introduction of policies, education authorities and tourism industry introduce policies from different angles, work together to clearly divide tourism education, deepen tourism education development reform and 
improve tourism education school running quality after deeply studying of the development of tourism schools. This will bring more and more far-reaching impact on the development of tourism education in China.

\section{B. Work hard to improve the quality of training}

As the rapid development of tourism education in China, there has been an oversupply of tourism talent, but the tourism enterprises is still unable to recruit the right candidates in the production process. Tourism-related majors in China expand the scale, but in the expansion schools haven't carried out positioning according to market need and the development of tourism industry. Therefore, tourism related majors don't have clear type, quantity, structure, teaching mode, teaching method and training goal of tourism special talents in the development of tourism education. The tourism education personnel training structure is lack of balance, causing supply and demand dislocation.

The Ministry of Education and the tourism industry management departments should increase the supervision, guidance and support of tourism education, so as to better guide the tourism teaching. On the basis, the national educational institutions should put forward demand, set standard and determine direction, and deeply promote it through school-enterprise cooperation platform. In the future development of tourism education, the Ministry of Education and the tourism industry attach importance to the development of tourism education in China. In the deep studying, development and cooperation of school, research and industry, divide tourism education into different levels, clearly determine the development target of tourism education, improve schoolrunning quality of China's tourism education, and actively strive to cultivate tourism education talents and specialty, promoting the sustainable development of China's tourism education.

\section{Increase international communication and cooperation}

International tourism professionals need to have an international perspective, master tourism practice experience, acquire international communication and cooperation capacity. China's tourism education needs to rely on the international background, vigorously carry out cross-cultural exchanges and cooperation. To carry out cross-cultural education is inseparable from teaching staff with cross-cultural background and quality. And in China's tourism education, tourism teachers training links are lack of "going out" strategy and cross-cultural exchange experience. Germany often selects teachers to go to colleges in different countries and different regions for experience and further study. It encourages teachers to conduct cross-school, cross-regional and cross-international cooperation research, and guide teachers to experience and practice in different cultural areas and cultural activities, so as to cultivate their multicultural ideas and cross-cultural communication skills. China's tourism education should also act on international convention, train tourism teachers' multicultural communication capacity, and actively expand the diversified vision of China's tourism teachers, so that teachers can correctly treat different cultural issues. Increase the introduction of cross-cultural educational talents to enhance the level of tourism education in China.

\section{CONCLUSION}

The tourism education of cooperative education colleges in Germany is based on the dual education system. The classification of tourism courses varies with different enterprises and institutions. Tourism higher education in Germany allows students to enter other countries to have diversified university studies, increase practical skills and international experience, and learn transnational strategies. Germany pays more attention to the general education on the requirements of tourism managers. Compared to the comprehensive colleges in Germany, the training in university of applied science in Germany pays attention to the applicability over the systematization of theoretical knowledge. The tourism enterprise teaching application management center outside the school is mainly formed by relevant professional teachers and instructors sent by the school. According to the teaching plan, understand the task and purpose of each teaching link and determine the instructor and tourism enterprise related personnel. China's tourism management major has not yet formed a system like the tourism education in German's comprehensive university, applied science university and cooperative running colleges. China's tourism colleges have not been classified into academic research school and practical application school. China should increase the adjustment of tourism education reform. In the deep studying, development and cooperation of school, research and industry, divide tourism education into different levels, clearly determine the development target of tourism education, improve schoolrunning quality of China's tourism education, and actively strive to cultivate tourism education talents and specialty, promoting the sustainable development of China's tourism education. And in China's tourism education, tourism teachers training links are lack of "going out" strategy and cross-cultural exchange experience.

\section{ACKNOWLEDGMENT}

Fund Project: This article is funded by Jilin province higher education reform research topic "Exploration and Practice of Tourism Undergraduate Education Comprehensive Reform Based on Applied Personnel Training" (20154609), Jilin province higher education society higher education research project " Innovation and Practice of Applied Tourism Higher Education Practice Teaching Pattern"(JGJX2017D125), and Changchun Normal University graduate education innovation project "The Enlightenment of German Tourism Higher Education Teaching Classification to China's Teaching from the Perspective of Application" (CSCXY2017012).

Author: Liu Haiyang (1982 -), male, come from Suihua Heilongjiang, Ph.D., associate professor and master tutor of School of History and Culture, Changchun Normal University, postdoctor of Chinese Academy of Sciences Northeast Institute of Geography and Agricultural Ecology. Mainly study tourism economy and regional development. 


\section{REFERENCES}

[1] Albrecht J N. Authentic learning and communities of practice in tourism higher education.[J]. Journal of Teaching in Travel \& Tourism, 2012, 12(3):260-276.

[2] Holden A, Wickens E, Wickens E, et al. 'Citizen of the world' or 'management puppet'? The place of tourism studies in higher education.[J]. Tourism Recreation Research, 2007, 32(2):41-47.

[3] Eurico S, Valle P O D, Silva J A, et al. Segmenting graduates consumers of higher education in tourism: An extension of the ECSI Model[J]. Spatial \& Organizational Dynamics Discussion Papers, 2012.

[4] Sangpikul A. Internationalization of hospitality and tourism higher education: a perspective from Thailand.[J]. Journal of Teaching in Travel \& Tourism, 2009, 9(1-2):2-20.
[5] Fadli Fizari A H A, Idris A R, Daud N M. Modelling education tourism using gravity model in Malaysian public higher education institutions.[J]. China Science \& Technology Information, 2011, 5(5):1257-1274.

[6] Guo Y Z, Chen Y, Freyer W, et al. An Introduction to the Tourism Educational System in Germany under the International Background[J]. Tourism Tribune, 2005.

[7] Granow R, Bischoff M. Virtual University of Applied Sciences--German Flagship Project in the Field of E-Learning in Higher Education.[C]// World Conference on E-Learning in Corporate, Government, Healthcare, and Higher Education. 2002:8.

[8] KLAUS HÜFNER. Governance and Funding of Higher Education in Germany[J]. Higher Education in Europe, 2003, 28(2):145-163. 